TITLE:

\title{
Progranulin Expression in Advanced Human Atherosclerotic Plaque(Abstract_要旨)
}

$\operatorname{AUTHOR}(S)$ :

Kojima, Yoji

CITATION:

Kojima, Yoji. Progranulin Expression in Advanced Human

Atherosclerotic Plaque. 京都大学, 2009, 博士(医学)

ISSUE DATE:

2009-03-23

URL:

http://hdl.handle.net/2433/124322

RIGHT: 


\begin{tabular}{|l|l|c|l|}
\hline 京都大学 & 博士 (医学) & 氏 名 & 小島 洋児 \\
\hline 論文題目 & $\begin{array}{l}\text { Progranulin Expression in Advanced Human Atherosclerotic Plaque } \\
\text { (進行したヒト動脈硬化巣における progranulin の発現) }\end{array}$ \\
\hline
\end{tabular}

\section{（論文内容の要旨）}

Progranulin(PGRN)は 7 個半の granulin ペプチド(GRNs)が直鎖状に連なったタンパ クで、創傷治瘉において重要な役割を担っていることが近年報告された。PGRN は抗炎 症作用の他に、細胞増殖作用も持つ。一方で、好中球プロテアーゼによって granulin ペ プチドに分解されると、反対に催炎症作用をもたらすことが知られている。

創傷治瘉で見られるような、傷害、炎症、修復、といった過程は、動脈硬化の進展に大 きく関わっていることが知られており、PGRN が動脈硬化の進展に対しても重要な作用 を担う可能性があり、今回、その発現や作用について検討した。

まず実際の動脈硬化巣において PGRN の産生細胞を確認した。ヒトの頚動脈内膜剥離 術で採取されたサンプルを用いて、免疫染色を行ったところ、血管平滑筋細胞、中でも中 膜や線維被膜の平滑筋でなく、内膜内にある平滑筋細胞での発現を認めた。また、同様に 内膜内のマクロファージも一部 PGRN を発現していた。

動脈硬化の進展に際して、マクロファージの内膜への浸潤、平滑筋の内膜内一の遊走は 重要な過程の一つである。そこで、これらの細胞に対する PGRN の作用について実験を 行った。単球/マクロファージはヒト単球性白血病細胞 THP-1 を、平滑筋細胞としては Human Arterial Smooth Muscle Cell(HASMC)を用いた。まず、上記の細胞を用いて migration assay を行ったところ、THP-1 細胞、HASMC とも PGRN 単独ではほとんど 変化を認めなかった。しかし、THP-1 細胞を Monocyte Chemotactic Protein-1 と PGRN とで刺激した際には、PGRN の濃度依存性に遊走細胞数は減少した。逆に HASMC を Tumor Necrosis Factor(TNF)- $\alpha$ と PGRN とで刺激した際には、10nM の容量では遊走 細胞数は増加したが、それ以上の濃度では増加は認めなかった。単球の遊走に関しては、 PGRN は阻害的に作用することが確認できた。

次に、動脈硬化巣において Interleukin-8(IL8)は内皮細胞や平滑筋細胞、単球の 遊走を促し、病変の進展にかかわることが知られているため、平滑筋細胞におけ る PGRN-GRNs の IL-8 分泌に対する影響を評価した。まずレンチウィルスを用い て PGRN を過剩発現する系と、RNAi を用いてノックダウンする系を作成した。 これらを用いて HASMC の PGRN の発現を変化させると、PGRN 過剩発現では TNF- $\alpha$ 刺激下の IL-8 分泌を抑制し、PGRN ノックダウンではTNF- $\alpha$ 刺激下の IL-8 分泌を促進した。さらに、分泌された PGRN の影響を評価するために、リコンビナン トPGRN を作成し、PGRN 単独、あるいは好中球エラスターゼにより GRNs に切断した ものとでHASMC を刺激した。その結果、PGRNはTNF- $\alpha$ 刺激下の IL-8 分泌を抑制 し、GRNs では TNF- $\alpha$ 刺激下の IL-8 分泌を促進した。

これらの結果から、(1) ヒト動脈硬化病変では内膜内の平滑筋とマクロファージが PGRN を発現していること。(2)単球に対しては、PGRN は遊走に抑制的に働くこと。(3) 平滑筋細胞に対しては、IL-8 分泌制に働くこと。(4)PGRN が GRNs に切断されると IL -8 分泌を増強する方向に作用することが判明した。従って、PGRN- GRNs は動脈硬化 の進展に影響を及ぼしうることを示した。
(論文審査の結果の要旨)

Progranulin は創傷治癒において重要な役割を持つタンパクである。動脈硬化の進展 こおいても、炎症と組織修復という点で創傷治癒と同様に progranulin が関わってい ると考えられ、申請者はヒトの動脈硬化病変での発現と作用機序を検討した。

この目的で、(1) ヒ上動脈硬化病変で免疫染色を行い、籷腫内膜内の平滑筋細胞とマ クロファージが progranulin を発現していること、さらに、培養細胞系で、(2)単球に 対して progranulin は遊走を抑制に作用することを確認した。また、(3)平滑筋細胞に 対しては、progranulin を強発現した場合も、外部からの progranulin 刺激でも、IL-8 分泌の点で抑制的に働くこと、(4)さらに progranulin が granulin に切断されると、逆 に Il-8 分泌を増強することが判明した。

これらの結果から、progranulin はヒ卜動脈硬化巣において発現されており、単球遊 走及び IL-8 分泌を介して、 prigranulin-granulin が動脈硬化の発展過程に影響を及 ぼしうる可能性が示された。

以上の研究で、申請者はヒトの動脈硬化病変で progranulin の発現を初めて明らか にし、動脈硬化進行における病態的意義について解析を行った。このように動脈硬化 に対する新規分子の関与を指摘した点において新たな機序解明の糸口として寄与する ところが多い。

したがって、本論文は博士（医学）の学位論文として価值あるものと認める。 なお、本学位授与申請者は、平成 21 年 3 月 4 日実施の論文内容とそれに関連した試問 を受け、合格と認められたものである。 